\section{Ks. Wojciech Pikor}

Uniwersytet Mikołaja Kopernika, Toruń

pikor@umk.pl

DOI: http://dx.doi.org/10.12775/BPTh.2017.014
Biblica

et

Patristica

Thoruniensia

10 (2017) 2: 291-295

ISSN (print) 1689-5150

ISSN (online) 2450-7059

\title{
Book review: Michele Mazzeo, La cura della vita. Bibbia e bioetica, Collana BIBLICA, Bologna: Edizioni Dehoniane, 2015, pp. 411, ISBN 978-88-10-22176-1
}

Keywords: "The Bible and Morality"; bioethics; biblical ethics.

Słowa kluczowe: „Biblia a moralność”; bioetyka; etyka biblijna.

In 2008 was published a document of the Pontifical Biblical Comission The Bible and Morality. Biblical Roots of Christian Conduct. The Pontifical Biblical Comission aspires two goals:

1. Show the specifity of Christian morality in relation to natural ethics and moralities built on the basis of human experience and intellect, and also in the context of ethical systems of other religions.

2. Indicate methodology of the Bible usage in discussion over contemporary moral problems which are not clearly or widely explained in the Bible or were entirely unknown in biblical times (no. 92 of the document mentions among such moral problems violence, terrorism, war, immigration, distribution of wealth, respect for natural resources, life itself, work, sexuality, research in the genetic field, family and community life).

The reception of the document The Bible and Morality. Biblical Roots of Christian Conduct in the Church was classic, at least when we talk about the Polish Church. The document did not become known in wide range of those believing in God, but it also did not become an inspiration for further research and studies among theologians. The reception was limited to a few scientific conferences (among others at John Paul II Catholic University of Lublin and the Pontifical University of John Paul II in Cracow) which treated the document with great recognition, however a critical reading of its content was not conducted, especially in moral reflection of six specific criteria indicated in the second part of the document.

With great joy therefore we should receive the book by Michele Mazzeo La cura della vita which subtitle Bibbia e bioetica indicates the approach to this problem. The subject of concern for life is shown in the perspective of not only 
possible but also necessary dialogue between the Bible and bioethics. In the introduction the author clarifies the aim of his research "The reflection, which we propose in relation between the Bible and concern for life, allows to research this currently delicate problem of relation between the Bible and bioethics. We intend to show how the Holy Scripture «as one», namely both Testaments, is an important and inspiring place [for] the dialogue with contemporary human being also on issues touching morality and ethics of life" (p. 14).

Presented monograph is preceded with a substantial introduction (pp. 13-33) in which Mazzeo presents the Bible and bioethics as two different "pieces of wisdom" which have in their centres the reflection of a human being. This common interest in human life demands that these two pieces of wisdom remainded in dialogue. The fact that the term "bioethics" (Gr. biotiká) appears twice in the New Testament (in Luc 21:34 and 1 Cor 6:2-4) in the context of wisdom and ethics also seems to confirm that.

The monograph is made up of two parts, each part has three chapters. The first part is entitled "The Bible and bioethics. Lexis and the method of dialogue." opens the first chapter in which the author verifies the possibility of relation between the Bible and bioethics (pp. 39-58). After presenting the history of bioethics as a scientific discipline Mazzeo indicates its interdisciplinary nature which results in the necessity of dialogue with different scientific disciplines which are interested in human life, including biblical studies. The Bible contains anthropological, philosophical and ethical values which have produced positive influence on the whole humankind. (p. 53) The second chapter tackles the subject of possible dialogue between the Bible and bioethics out of concern for human life (pp. 59-114). The author seeks for a model of this dialogue in three dialogues of Jesus about life presented in the Gospels: with the teachers of the Law, using the Parable of the good Samaritan (Luk 10, 23-37), with a rich young ruler about the way of achieving eternal life (Luk 18:18-30) and with the Pharisees due to their reservations about the legality of healing a man with a withered hand during the Sabbath (Mar 3:1-6). In the third chapter (pp. 115-169) the author analyses the lexis used in the Bible in reference to human life (among others Greek terms prósōpon, bios, zōe, biōtiká) in order to clarify the concept of life proposed in the Bible.

The second part of the monograph tries to explain, in a more practical way, the issue of 'the dignity and mystery of human life' always starting with the biblical texts. In the fourth chapter the author (pp. 175-239) analyses the usage of term biotiká by Jesus in eschatological discourse (Luk 21:5-38; Greek syntagma merímnais biötikaîs in v. 34) and by Paul in connection with "the criteria [of judgement] of everyday life" (Greek syntagma biōtiká kritēria in 1 Cor 6:4). Even more existential is the fifth chapter of the monograph 
(pp. 242-305) in which the author using biblical texts (above all Psalm 139) brings closer the dignity of the beginning of life (from the moment of conception) placing it in the context of God's "project" of life, namely marriage and family (in this case he refers mainly to Mar 10:1-9, crucial for the understanding of the Jesus' teaching about marriage). The final, sixth chapter, of the monograph - in accordance with its title - "The results and perspective of the dialogue the Bible - bioethics" (pp. 307-360) is the culmination and at the same time it opens further possibilities of fruitful exploitation of the Bible by bioethics. Mazzeo proposes the following structure of bioethics: 1 . 'preventive' bioethics based on respect and love towards human life (agapetic perspective), 2. bioethics respecting relational structure of human being, 3 . narrative bioethics referring to narrative human identity, 4 . dialogic bioethics which has interdisciplinary character, acknowledges complexity of human life.

\section{Why is the reviewed book worth reading?}

Firstly, it is the first monograph within biblical studies in which the author examines relations between the Bible and bioethics founded on the exegesis of religious texts. The proposed analysis of biblical texts is by all means scientific, it is also understandable for readers who are not biblical scholars. Recognition raise these fragments of the book where the author carries semantic analysis of biblical terms crucial for the Bible - bioethics dialogue at the top of the discovery of term biōtiká in the New Testament.

Secondly, the author seeks methodology which will allow for practical usage of the Bible in solving contemporary bioethical problems, for example National Human Genom Research or Type 2 Diabetes Research. In this context we should mention that the author as a model of interdisciplinary research conducted in the field of bioethics proposes the way Jesus talked to others about subjects concerning human life (pp. 110-114).

Thirdly, presented monography examines relations between the Bible and bioethics proposing new look at certain problems occuring in biblical hermeneutics. As an example we can point at the author's approach to semantic analysis (pp. 164-165) or narrative analysis (p. 326-351).

Fourthly, the author neither limits himself only to the past (the analysis of biblical texts) nor only to the present (analysis of relations between the Bible and bioethics) but in his studies he looks into the future. In the perspective of the future he presents the above mentined concept of bioethics and encourages biblists to interdisciplinary dialogue. Their presence is crucial while solv- 
ing bioethical problems because one cannot understand subjects of human life without the biblical perspective (pp. 358-359).

Finally, the presented book is a huge hymn in honour of human life which comes from God. Mazzeo reminds that bioethics, according to its etymology, has to remain 'ethics of life', serves life - every life.

The monograph "La cura della vita" does not aspire to exhaust the subject of relation between the Bible and bioethics. Undoubtedly it is an incentive and inspiration for further dialogue between biblical scholars and bioethicist or moral theologians.

In this context I will allow myself for a few critical remarks about the reviewed monograph. As I have mentioned the value of this book constitute, among other things, semantic analysis of Hebrew and Greek terms. On the basis of these the author reconstructs biblical concept of human being. As the starting point Mazzeo proposes the analysis of Hebrew verb yāda' (pp. 25-27) to be able to talk about the "relational cognition". He connotes it as "recognition which allows not only to think but also creates relation/contact with people it takes care of committing its whole life" (p. 27). However earlier to "relational cognition" described with this verb Mazzeo refers as to "sexual cognition in a sense of sexual intercourse of a man and a woman". Relationality of this verb in a sense of care, cherish and choice of the other demands referance to other texts which were not mentioned by Mazzeo (cf. Gen 19:18; Jer 1:5; Amo 3:2).

In the context of relationality of human being a reservation raises the way in which the author elaborates terms describing the diversity of sex as "man" and "woman" (pp. 154-155). Neither Hebrew terms from Gen 1:27 nor narration from Gen 2 are cited. In light of these two texts diversity of sex is constitutive for a human being. Question about the sense of this diversity in the context of narration Gen 1-11 is still open. The author rightly sees it in marriage (cf. p. 285), however, the narrative analysis recommended by him as a method of dialogue between the Bible and bioethics requires to ask about the sense of resemblance of human to God as a man and a woman [in biblical text human by being "a man and a woman" is a picture of God].

The above mentioned problem shows that biblical anthropology in substantial degree is narrative - it can be reconstructed by the analysis of biblical narrations. Therefore we should highlight the rightness of 'narrative bioethics' postulate (pp. 326-351). It must be, however, specified more precisely. It is not clear what the author understands by "narrative medicine" (p. 334). It seems that he equates two different narratives: story as a therapy tool and interview (by a doctor with a patient) as an element of medical diagnostics. Undoubtedly the idea of narrative bioethics becomes part of the Bible - bioethics dialogue. Narration is the basic form of communication of the word of God via Holy 
Scripture. There is still, however, the question about the form of not only narrative bioethics but also narrative theology.

The above mentioned remarks only confirm that bioethics must be dialogic and interdisciplinary, open to biblical narration. The book La cura della vita is its superb evidence.

\section{References}

Pontifical Biblical Commission, The Bible and Morality. Biblical Roots of Christian Conduct, Città del Vaticano 2008.

De Virgilio G., „La «proposta ermeneutica» nel documento della Pontificia Commissione Biblica: Bibbia e morale. Radici bibliche dell'agire cristiano", Annales Theologici 25 (2011) 95-119.

De Virgilio G., „La Sacra Scrittura alla base di unetica applicata. Problemi e prospettive", w: V. Viva, G. Witaszek (red.), Etica teologica nelle correnti della storia. Contributi dall'Accademia Alfonsiana al secondo Congresso mondiale dei teologi morali cattolici, Città del Vaticano 2011, 51-61.

Machinek M., „Miejsce egzegezy biblijnej w metodologii teologiczno-moralnej. Uwagi na marginesie dokumentu Papieskiej Komisji Biblijnej Biblia a moralność,', w: B. Mielec (red.), Biblia o moralności. Wokół dokumentu Papieskiej Komisji Biblijnej Biblia a moralność. Biblijne korzenie postępowania chrześsijańskiego, Kraków 2010, 21-52.

Mazzeo Michele, La cura della vita. Bibbia e bioetica, Collana BIBLICA, Edizioni Dehoniane, Bologna 2015.

Siker J.S., Scripture and Ethics. Twentieth-Century Portraits, New York-Oxford 1997. 